\title{
The Effect of Using English Videos on Vocabulary Achievement at the Fifth Grade of Elementary School 10 Poasia
}

\author{
Ni Nyoman Ayu Novayanti \\ Halu Oleo University \\ ayunovayanti27@gmail.com \\ Meilan Nirmala Shinta \\ Halu Oleo University \\ meilanshinta@rocketmail.com
}

\author{
Mursalim \\ Halu Oleo University \\ mmursalim@yahoo.com \\ Amir Jaya \\ Halu Oleo University
}

\begin{abstract}
Vocabulary is often regarded as the foundation of four main skills of English; listening, speaking, reading, and writing. It is important to look for the ways how teaching vocabulary can be effective and integrated into those skills. This study aims at finding out the effect of using English videos on vocabulary achievement at the fifth grade of Elementary School 10 Poasia. It used quasi experimental design which involved two classes; experimental and control class. By using purposive sampling technique, the sample was second semester students class $V$.A as experimental class and class $V$.B as control class. Both classes consisted of 28 students. The instrument of this study was vocabulary test that consisted of 21 numbers of questions and used SPSS 16 to analyze the data. The result shows that there is a significant effect of using English videos on students' vocabulary achievement. It is proven by descriptive analysis in which students' mean score of experimental class was 39.3 in pretest and 77.7 in posttest, meanwhile students' mean score of control class was 33.9 for pretest and 56.1 for posttest. Furthermore, the result of hypothesis testing showed that the value of Sig (2-tailed) was 0.001 which smaller than 0.05 , means that $\mathrm{HO}$ is rejected and $\mathrm{H1}$ is accepted. Therefore, it can be inferred that there is a significant effect of using English videos on students' vocabulary achievement.
\end{abstract}

Keywords: Audio Visual Media, Vocabulary Achievement, Young Learner

\section{INTRODUCTION}

In Elementary school curriculum, English is taught as a local content subject (muatan lokal). Local content subject means that English is taught based on the needs of the school or the needs of the territory. Elementary school students are usually taught English once a week. It aims to make students being well-prepared to continue for Junior and Senior high school in which English is a compulsory subject to be learnt. Hence, the rules of teaching English as a local content subject are usually arranged with good hearings and attentions by the principal and all stakeholders.

Teaching English as foreign language is not an easy task. There are several factors that strongly influence students as foreign language learner. One of the factors that may take a crucial role is vocabulary knowledge which is often viewed as a very basic thing in language learning. Vocabulary is a branch of language learning which plays a great role in acquiring language. Wilkins [1] claims "without grammar, very little can be conveyed. Without vocabulary, nothing can be conveyed". This means knowing a great amount of vocabulary is actually favorable to learners in language learning. It enables students to interpret and to speak more. In short, a great amount of vocabularies is required for being competent in a foreign language learning.

Teaching vocabulary for young learners is not as easy as what is expected. There are some particular things that should be known and comprehended by teachers. It is important to know that young learners or elementary school students are different from adult learners. They have their own behavior and characteristics that will be showed in learning process. It also has to be considered that children have a flexible emotional condition that will influence their learning activity. In brief, teaching young learners makes teachers should deal with children whose characteristics are different from adults' characteristics.

One of important components in designing model of teaching and learning vocabulary is the use of media. [2] state that besides knowing young learners' characteristics, one of key principles in devising effective learning activity is the application of instructional media. Media itself is defined by Gagne in [3] as "various components in learners' environment which support the learners learn".

Using video as the media of teaching and learning activity is a familiar thing. Kunari as cited in [4] argue that using audio visual aids in teaching is one way to improve lesson plans and give students ways to process subject information. It is very beneficial to teachers and students because teachers can give information and show what they are discussing about and it is easier to students especially 
for young learners in understanding and accepting information because they can watch directly what teachers mean relating to the materials.

Based on the background of the study, the research question in this study is "Is there any significant effect of using English Videos on vocabulary achievement at the fifth grade of Elementary school 10 Poasia?"

\section{METHOD}

This study applied quasi experimental research design which involved two classes; experimental and control class. The sample was second semester students class V.A as experimental class and class V.B as control class. It was selected by using purposive sampling technique. Both classes consisted of 28 students. Experimental class was taught vocabulary through the use of video. Meanwhile the control class was not. The instrument of this study was vocabulary test that consisted of 21 questions and used SPSS 16 to analyze the data. After the data was collected, it was continued by applying Independent sample t-test to test the hypothesis.

\section{RESULT}

The finding show descriptive statistics of pre-test and post-test in experimental and control class according Table 1.

The finding shows the descriptive statistics of pretest and post-test both in experimental and control class. Those two classes had 28 students as participants of pretest and post-test. Based on the table above, the lowest minimum score was in pre-test of control class (0) and the highest minimum score was post-test of experimental class (48). While the maximum score, both the two classes had same score in the post-test (100). Accordingly, the mean score of experimental and control class is both improved, but there is a difference improvement.

The pre-test mean score of experimental class was 39.3 and in the post-test became 77.7. Meanwhile, the mean score of control class in pre-test was 33.9 and became 56.1 for the post-test. Hence, the mean score of experimental class was more improved than control class.

Table 1: Descriptive statistics of pre-test and post-test

\begin{tabular}{|c|c|c|c|c|c|}
\hline & $\mathrm{N}$ & Minimum & Maximum & Mean & $\begin{array}{l}\text { Std. } \\
\text { Deviation }\end{array}$ \\
\hline $\begin{array}{l}\text { Pre-test } \\
\text { Experimental }\end{array}$ & 28 & 5.00 & 76.00 & 39.3929 & 20.04502 \\
\hline $\begin{array}{l}\text { Post-test } \\
\text { Experimental }\end{array}$ & 28 & 48.00 & 100.00 & 77.7857 & 15.72297 \\
\hline $\begin{array}{l}\text { Pre-test } \\
\text { Control }\end{array}$ & 28 & .00 & 95.00 & 33.9643 & 24.57111 \\
\hline $\begin{array}{l}\text { Post-test } \\
\text { Control }\end{array}$ & 28 & 10.00 & 100.00 & 56.1429 & 22.63513 \\
\hline $\begin{array}{ll}\text { Valid } \\
\text { (listwise) }\end{array}$ & 28 & & & & \\
\hline
\end{tabular}

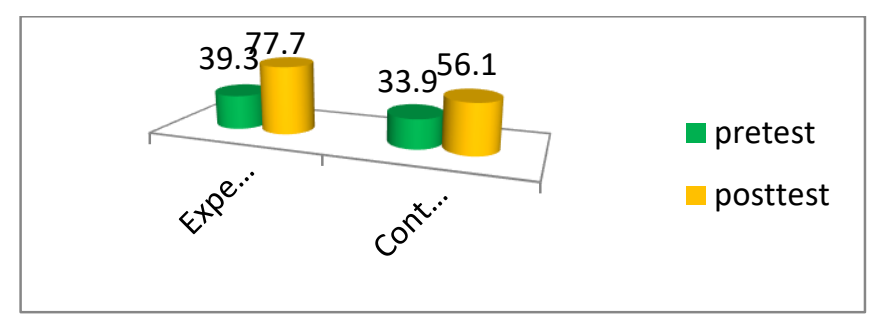

Figure 1: The Comparison of Mean Score on Pre-test and Post-test in

The pre-test mean score of experimental class was 39.3 and in the post-test became 77.7. Meanwhile, the mean score of control class in pre-test was 33.9 and became 56.1 for the post-test. Hence, the mean score of experimental class was more improved than control class.

The last column is standard deviation. A good value of standard deviation is the closer to 0 . It can be seen from the table, the value in the experimental class was 20.04 for pre-test and became 15.72 for post-test. It means there was an improvement of data transmission. The improvement of standard deviation was also in control class, but it was not as significant as experimental class. The value was improved from 24.57 to 22.53 . The value of experimental class was more increased than control class. Furthermore, this chart below provides the comparison of mean score between two classes.

\section{Experimental and Control Class}

As can be seen that the mean score of pre-test in the experimental class was 39.3 and it was improved become 77.7 in the post-test. It appears that the gain score was 38.4. Meanwhile, the mean score of pre-test in control class was 33.9 and became 56,1 in the post-test. It creates 22.2 for the gain score. Even though the mean score of control class was also improved, but it was not as significant as experimental class. The mean score of posttest of experimental class is higher than control class. The mean score of experimental class is enhanced by applying English video as supporting media which helps students during learning.

Based on the result of the normality test, the data of both two classes were analyzed by using independent sample t-test to find out the homogeneity of the data and to test the hypothesis whether there was a significant effect of English videos on young learners' vocabulary or not.

The data shows independent sample t-test gives two kinds of information namely Equal variances assumed and Equal variances not assumed. Above table explains if the variances were homogenous because Sig. value was .507 which was higher than 0.05 (Sig. > 0.05), it can be concluded that the variance is homogenous. Thus, Sig. (2tailed) was 0.001 which lower than 0.05 (Sig. (2-tailed) < $0.05)$. Hence, it can be concluded that $\mathrm{H} 0$ was rejected and H1 was accepted which means that there is a significant effect of using English video on young learners' vocabulary achievement at the fifth grade of Elementary School 10 Poasia.

The use of video as an audio visual media during teaching and learning process can help students to improve their vocabulary achievement. It is because video presents 
learning material which can be seen and listened directly. It increases students interest and can help students in preserving their focus. This result is supported by Brumfit $(1983 ; 7)$ who argues that video is most widely used to introduce and stimulate interest in a topic, to give information on cultural background and for general language. Another research found that the use of video can enhance learning because when students are presented an audio visual aid, they get specific fixed expression, they enjoy it, find it motivating and affect them [5].

The use of subtitle also takes important role in the use of video. Subtitle makes students can obtain more the information presented by the video. Students are helped in getting the written form of each word, remembering most students (foreign language learners) assume that English has difficult written form of language. The writer can watch that during the treatments, the use of subtitle which can be both seen and listened guide students in exploring and elaborating their learning materials. By the subtitle, students also take more interest, and back up each other to be involved during the treatments.

The researcher found that using video is very interesting for students. It makes their attentions focus on the material in the video. Students may consider this in a new model of teaching and learning during their classes. It can be seen when the bell was ringing for English class, students entered their classroom immediately. They were waiting for the teacher who was preparing all of the tools; computer, speaker, and projector. Students waited silently, they did not disturb each other, and they also did not talk each other. It happened till the video was played, in which students were focus on the video and finished their sheets. That was a very contrary to the control class, some students still disturbed and talked each other during teaching and learning. Their focus was increased when teacher asked them to check their work in the dictionary. In brief, the writer may ascribe that video is an interesting media which can keep and improve students' focus during the class.

\section{CONCLUSION}

This present study found that there is a significant effect of using English videos in improving students' vocabulary achievement.
Based on the finding and discussion, the researcher draws the following conclusions: 1) English video has positive effect toward students' vocabulary achievement. It is proven by students' learning activity where they feel more interesting and minim of anxiety during teaching and learning activity. It is also proven by students' score on vocabulary test that showed significant improvement. 2) Students have high interest to learn vocabulary through video. It helps them in looking after their attention and increasing their focus on material presented by the video. 3) The perceived advantages of using video for teaching and learning are:

1. It is easier to get and interpret the materials. It is because video is a kind of audio visual media. Students are helped to gain and explore their knowledge after they watch and listen to the materials presented in the video.

2. It coincides helping students to practise other skills like listening and speaking. It can be seen when watching the video, students try to get the information and know how to pronounce the words presented.

3. The good achievement of vocabulary leads students' ability into four skills of language. It is because vocabulary knowledge is a basic of language that support listening, speaking, reading, and writing.

\section{REFERENCES}

[1] Aini, W. N. Instructional Media in Teaching English to Young Learners: A Case Study in Elementary Schools in Kuningan. 196-205. 2013.

[2] Alqahtani, Mofareh. The Importance of Vocabulary in Language Learning and How to be Taught; International Journal of Teaching and Education, (3). 21-34. 2015.

[3] Arslan, Gun, and Ustunel. Teaching vocabulary to Turkish young learners in semantically related and semantically unrelated sets by using digital storytelling; Journal of Language and Linguistic Studies, (1). 42-54. 2015.

[4] Askar, W. A. A Survey on The Use of Vocabulary Learning Strategies by ELT and ELL Students of Duhok University in Kurdistan; International Academic Research Conference, 413-473. 2016.

[5] Brumfit, C. J. Video Applications in English Language Teaching. 1983. 